Research Article

\title{
Epistasis and genotype-by-environment interaction of grain protein content in durum wheat
}

\author{
Fethi Bnejdi and Mohamed El Gazzah \\ Laboratoire de Génétique et Biométrie, Département de Biologie, Faculté des Sciences de Tunis, \\ Université Tunis El Manar, Tunisia.
}

\begin{abstract}
Parental, $\mathrm{F}_{1}, \mathrm{~F}_{2}, \mathrm{BC}_{1}$ and $\mathrm{BC}_{2}$ generations of four crosses involving four cultivars of durum wheat (Triticum durum Desf.) were evaluated at two sites in Tunisia. A three-parameter model was found inadequate for all cases except crosses Chili $x$ Cocorit 71 at site Sidi Thabet and Inrat 69 x Karim at both sites. In most cases a digenic epistatic model was sufficient to explain variation in generation means. Dominance effects $(\mathrm{h})$ and additive $\mathrm{x}$ additive epistasis (i) (when significant) were more important than additive (d) effects and other epistatic components. Considering the genotype-by-environment interaction, the non-interactive model ( $\mathrm{m}, \mathrm{d}, \mathrm{h}, \mathrm{e})$ was found adequate. Additive variance was higher than environmental variance in three crosses at both sites. The estimated values of narrow-sense heritability were dependent upon the cross and the sites and were $0 \%-85 \%$. The results indicate that appropriate choice of environment and selection in later generations would increase grain protein content in durum wheat.
\end{abstract}

Key words: epistasis, genotype $\mathrm{x}$ environment interaction, heritability, grain protein, wheat.

Received: March 10, 2009; Accepted: October 14, 2009.

\section{Introduction}

Durum wheat (Triticum durum Desf.) is the most important cereal crop in Tunisia and North Africa, and is used primarily for couscous, macaroni and various types of bread (Troccoli et al., 2000). In addition, wheat of high grain protein content usually commands a premium price. The grain protein content of durum wheat is an important trait for the nutritional value of grain and the technological properties of flour (Blanco et al., 2006). The unpredictability of the Mediterranean climate causes fluctuations in wheat yield and quality, but offers the opportunity for obtaining high-quality durum wheat in terms of grain protein content (Rharrabti et al., 2001). The higher-yielding cultivars of Tunisia tend to have low grain protein, whereas the lower-yielding cultivars tend to have high grain protein. This inverse relationship between wheat yields and grain protein content is well known (Terman et al., 1969; Entz and Fowler, 1989; Pleijel et al., 1999). Genetic differences and environmental effects on grain protein content have been reported previously (Kramer, 1979; Baenziger et al., 1985). A range of heritabilities for grain protein content have been found in bread wheat: 47\%-83\% (Ekiz et al., 1998); 39\%-61\% (Guthrie et al., 1984); 30\%-76\% with a mean of 44\% (Duffield et al., 1972). Many data indicate

Send correspondence to Fethi Bnejdi. Laboratoire de Génétique et Biométrie, Département de Biologie, Faculté des Sciences de Tunis, Université Tunis El Manar, 2092 Tunisia. E-mail: fethibnejdi@yahoo.fr. that in wheat the grain protein content is heritable and determined either by several genes (Johnson et al., 1968) or by one or two genes (Haunold et al., 1962; Cowley and Wells, 1980). Millet et al. (1992) concluded that grain protein content was largely determined by the maternal parent. The estimation of epistatic components of genotypic variance and genotype $\mathrm{x}$ environment interaction is unusual in genetic studies, as epistasis was considered to make only a small contribution to quantitative variation (Crow, 1987). However, recent studies indicate the contribution of epistatic effects and genotype $\mathrm{x}$ environment interaction to grain protein content in barley (Kaczmarek et al., 2002). In this study, a generation mean analysis methodology (Mather and Jinks, 1982) was used to estimate the inheritance of protein content in durum wheat. This method allows determining whether the protein content traits fit an additivedominance model and estimating the additive, dominance, and epistatic gene effects, as well as the environmental effects and the genotype $\mathrm{x}$ environment interaction (Mather and Jinks, 1982).

\section{Materials and Methods}

The study was carried out under rain-fed conditions at two locations in Tunisia (Mogran and Sidi Thabet), during the years 2005-2006. Sowing was done at the beginning of December. The Mogran area is characterized by loam soil and a sub-humid climate with an annual rainfall of about $700 \mathrm{~mm}$. The Sidi Tahbet area is also characterized by loam 
soil and a humid climate with an annual rainfall of about $400 \mathrm{~mm}$. Parental cultivars were selected for their differences in grain protein content. Plants were grown in a randomised complete block design with two replications, with a between-row spacing of $20 \mathrm{~cm}$ and a within-row spacing of $10 \mathrm{~cm}$. Harvest was done per plant, and the numbers of plants evaluated varied depending on the generation: in generations with greater segregation, such as $\mathrm{F}_{2}, \mathrm{BC}_{1}$ and $\mathrm{BC}_{2}$, a greater number of plants were evaluated. The grain protein content was assessed by Near-Infrared Reflectance Spectroscopy of grain flour of each individual plant, using an Inframatic 8600 flour analyser. Transforming the data by log, square root, arc-sine, and arc-sine of square root had no effect on data distribution or in removing epistatic effects. Analyses of variance by population and location using SAS software version 6 (SAS Institute, 1990) indicated that the replication and generation $\mathrm{x}$ replication effects were not significant. Therefore, the generation mean analyses were made without adjusting the data for replication.

Calculated means and variances were used to estimate the mid-parent (m), additive (d), and dominance (h) gene effects, as described by Rowe and Alexander (1980) following the method of Mather and Jinks (1982) for a three-parameter model. Adequacy of the additive-dominance model was determined by the chi-square $\left(X^{2}\right)$ test with three degrees of freedom and was accepted if $p>0.05$ (non-significant $X^{2}$ value). When the three-parameter model was inadequate (significant $X^{2}$ value), the interaction terms [additive $\mathrm{x}$ additive (i), additive $\mathrm{x}$ dominance $(\mathrm{j})$, and dominance $\mathrm{x}$ dominance (1)] were computed (Mather and Jinks, 1982). The genetic parameters [m, (d), (h), (i), (j), and (1)] were tested for significance using an unpaired $t$-test. Adequacy of the best fit model was determined by the $X^{2}$ test with three degrees of freedom and was accepted if $\mathrm{p}>0.05$ (non-significant $X^{2}$ value). The weighted least squares method was also used to estimate environmental and genotype $\mathrm{x}$ environment interactions. This method was applied to parents and $F_{1}$ only (Mather and Jinks, 1982).

\section{Heritability}

The homogeneity of variances of non-segregating generations was tested using Bartlett's test (Bartlett, 1937). When the variances were heterogeneous, the environmental variance $\left(\mathrm{V}_{\mathrm{E}}\right)$ was replaced by an adequate number of separate parameters and pooled to produce a single environmental variance. Additive, dominance, additive x dominance and environmental variance components were estimated using the maximum likelihood method with the observed variance of the six basic generations used as the initial weights $\left(\mathrm{df} / 2 * \mathrm{~S}^{2}\right)$ until the $X^{2}$ test value reached a minimum (Lynch and Walsh, 1998).

Narrow-sense heritability $\left(\mathrm{h}^{2}\right)$ was calculated as follows: $\mathrm{h}_{\mathrm{n}}^{2}=\mathrm{V}^{*}{ }_{\mathrm{A}} / \mathrm{V}^{*}{ }_{\mathrm{A}}+\mathrm{V}^{*}{ }_{\mathrm{D}}+\mathrm{V}_{\mathrm{E}}$, where $\mathrm{V}^{*}{ }_{\mathrm{A}}$ is the additive genetic component of variance, $\mathrm{V}^{*}{ }_{\mathrm{D}}$ the dominance genetic component of variance, and $\mathrm{V}_{\mathrm{E}}$ the environmental variance (Kearsey and Pooni, 1996).

\section{Results}

The mean values and variances for the analysed traits of the four crosses at the two sites are presented in Table 1. In all cases, depending on the site, the means of the parents

Table 1 - Plant means \pm SE for grain protein (\%) in parental and offspring populations from four crosses at two sites (Mogran and Sidi Thabet), with two replications.

\begin{tabular}{|c|c|c|c|c|}
\hline Population & Chili x Cocorit 71 & Inrat 69 x Karim & Inrat $69 \times$ Cocorit 71 & Chili x Karim \\
\hline & \multicolumn{4}{|c|}{ Sidi Thabet } \\
\hline $\mathrm{P}_{1}$ & $16.60 \pm 1.24 \mathrm{a}(\mathbf{2 0})^{\mathrm{y}}$ & $15.04 \pm 2.78 \mathrm{a}(\mathbf{2 0})$ & $15.04 \pm 2.78 \mathrm{ab}(\mathbf{2 0})$ & $16.60 \pm 1.24 \mathrm{a}(\mathbf{2 0})$ \\
\hline $\mathrm{BC}_{1} \mathrm{P}_{1}$ & $15.33 \pm 2.74 \mathrm{a}(\mathbf{5 0})$ & $14.30 \pm 2.73 \mathrm{a}(\mathbf{5 0})$ & $14.76 \pm 3.54 b(48)$ & $15.92 \pm 1.89 a(47)$ \\
\hline $\mathrm{F}_{1}$ & $16.58 \pm 1.13 \mathrm{a}(\mathbf{1 9})$ & $14.57 \pm 2.26 \mathrm{a}(\mathbf{2 6})$ & $16.50 \pm 2.48 \mathrm{a}(\mathbf{2 2})$ & $17.00 \pm 1.53 \mathrm{a}(\mathbf{1 9})$ \\
\hline $\mathrm{F}_{2}$ & $11.22 \pm 2.81 \mathrm{~b}(\mathbf{9 6})$ & $13.66 \pm 3.23 \mathrm{ab}(\mathbf{9 8})$ & $11.31 \pm 3.02 \mathrm{c}(\mathbf{9 4})$ & $13.73 \pm 2.31 \mathrm{~b}(\mathbf{9 7})$ \\
\hline $\mathrm{BC}_{1} \mathrm{P}_{2}$ & $11.07 \pm 1.68 b(\mathbf{5 3})$ & $12.32 \pm 2.76 \mathrm{bc}(\mathbf{5 0})$ & $11.05 \pm 2.88 \mathrm{c}(48)$ & $13.43 \pm 2.52 b(46)$ \\
\hline \multirow[t]{2}{*}{$\mathrm{P}_{2}$} & $11.40 \pm 1.98 \mathrm{~b}(\mathbf{2 0})$ & $11.45 \pm 2.39 \mathrm{c}(\mathbf{2 0})$ & $11.40 \pm 1.98 \mathrm{c}(\mathbf{2 0})$ & $11.45 \pm 2.39 \mathrm{c}(\mathbf{2 0})$ \\
\hline & \multicolumn{4}{|c|}{ Mogran } \\
\hline $\mathrm{P}_{1}$ & $12.60 \pm 1.99 \mathrm{a}(\mathbf{2 0})$ & $11.80 \pm 2.15 \mathrm{a}(\mathbf{2 0})$ & $11.80 \pm 2.15 \mathrm{a}(\mathbf{2 0})$ & $12.60 \pm 1.99 \mathrm{a}(\mathbf{2 0})$ \\
\hline $\mathrm{BC}_{1} \mathrm{P}_{1}$ & $12.13 \pm 3.57 \mathrm{ab}(\mathbf{5 2})$ & $11.26 \pm 3.21 \mathrm{a}(\mathbf{5 0})$ & $11.31 \pm 3.30 \mathrm{ab}(\mathbf{4 8})$ & $12.22 \pm 2.37 \mathrm{a}(37)$ \\
\hline $\mathrm{F}_{1}$ & $12.47 \pm 3.28 \mathrm{a}(\mathbf{1 9})$ & $10.46 \pm 3.02 \mathrm{ab}(\mathbf{2 6})$ & $12.72 \pm 2.18 \mathrm{a}(\mathbf{2 2})$ & $12.40 \pm 1.70 \mathrm{a}(\mathbf{2 3})$ \\
\hline $\mathrm{F}_{2}$ & $10.86 \pm 3.72 \mathrm{ab}(\mathbf{8 8})$ & $10.19 \pm 3.57 \mathrm{ab}(\mathbf{7 8})$ & $9.55 \pm 3.16 \mathrm{c}(\mathbf{8 4})$ & $10.44 \pm 2.47 \mathrm{ab}(\mathbf{9 8})$ \\
\hline $\mathrm{BC}_{1} \mathrm{P}_{2}$ & $10.46 \pm 2.77 b(\mathbf{4 3})$ & $10.52 \pm 2.99 \mathrm{ab}(\mathbf{5 0})$ & $9.92 \pm 3.32 b c(48)$ & $11.62 \pm 1.74 \mathrm{c}(46)$ \\
\hline $\mathrm{P}_{2}$ & $8.25 \pm 2.29 \mathrm{c}(\mathbf{2 0})$ & $9.10 \pm 2.26 \mathrm{~b}(\mathbf{2 0})$ & $8.25 \pm 2.29 \mathrm{c}(\mathbf{2 0})$ & $9.10 \pm 2.26 \mathrm{~b}(\mathbf{2 0})$ \\
\hline
\end{tabular}

Means followed by the same letter within each column for each site are not significantly different, based on Duncan's test $(\mathrm{p}<0.05)$. $\mathrm{y}=$ numbers in parentheses represent the plants evaluated in each generation. 
in each cross showed a tendency to be more extreme. The backcrosses $\mathrm{BC}_{1} \mathrm{P}_{1}$ and $\mathrm{BC}_{1} \mathrm{P}_{2}$ had means that tended to be close to those of their respective recurrent parents. These results confirmed the choice of parents for the present study. The $F_{1}$ means exceeded the superior parents for crosses Inrat 69 x Cocorit 71 and Chili x Karim at the Sidi Thabet site and for Inrat $69 \times$ Cocorit 71 at Mogran. In the majority of cases, the $F_{2}$ mean was higher than the $P_{2}$ mean and lower than the $\mathrm{F}_{1}$ mean.

The results of the three-parameter model and the best-fit model are listed in Table 2 . The joint scaling test revealed that the additive-dominance model was adequate in three cases; in other cases it was inadequate $(p<0.001)$. The failure of the model may be due to the influence of in- teraction or linkage among genes governing the inheritance of this trait. Therefore, the digenic epistatic model was applied and was found adequate; this adequateness ranged from 2 to $98 \%$. Additive (d) and dominance (h) effects were significant in the majority of crosses. For the crosses Chili x Cocorit 71 at Mogran, and Inrat $69 \times$ Karim at both Mogran and Sidi Thabet, protein content was adequately explained by an additive-dominance model, with the additive effect being more important than the dominance effect. For all other cases a digenic epistatic model was adequate. The additive effect was significant and positive in all crosses at the two sites. The dominance effect was not significant only for crosses Inrat 69 x Karim at Mogran and Chili x Karim at Sidi Thabet. For the digenic epistatic effect, the additive $\mathrm{x}$

Table 2 - Estimates of gene effects \pm SE for grain protein content in four crosses (Chili x Cocorit 71, Inrat 69 x Karim, Inrat $69 x$ Cocorit 71 , and Chili x Karim) at two sites (Mogran and Sidi Thabet), with two replications.

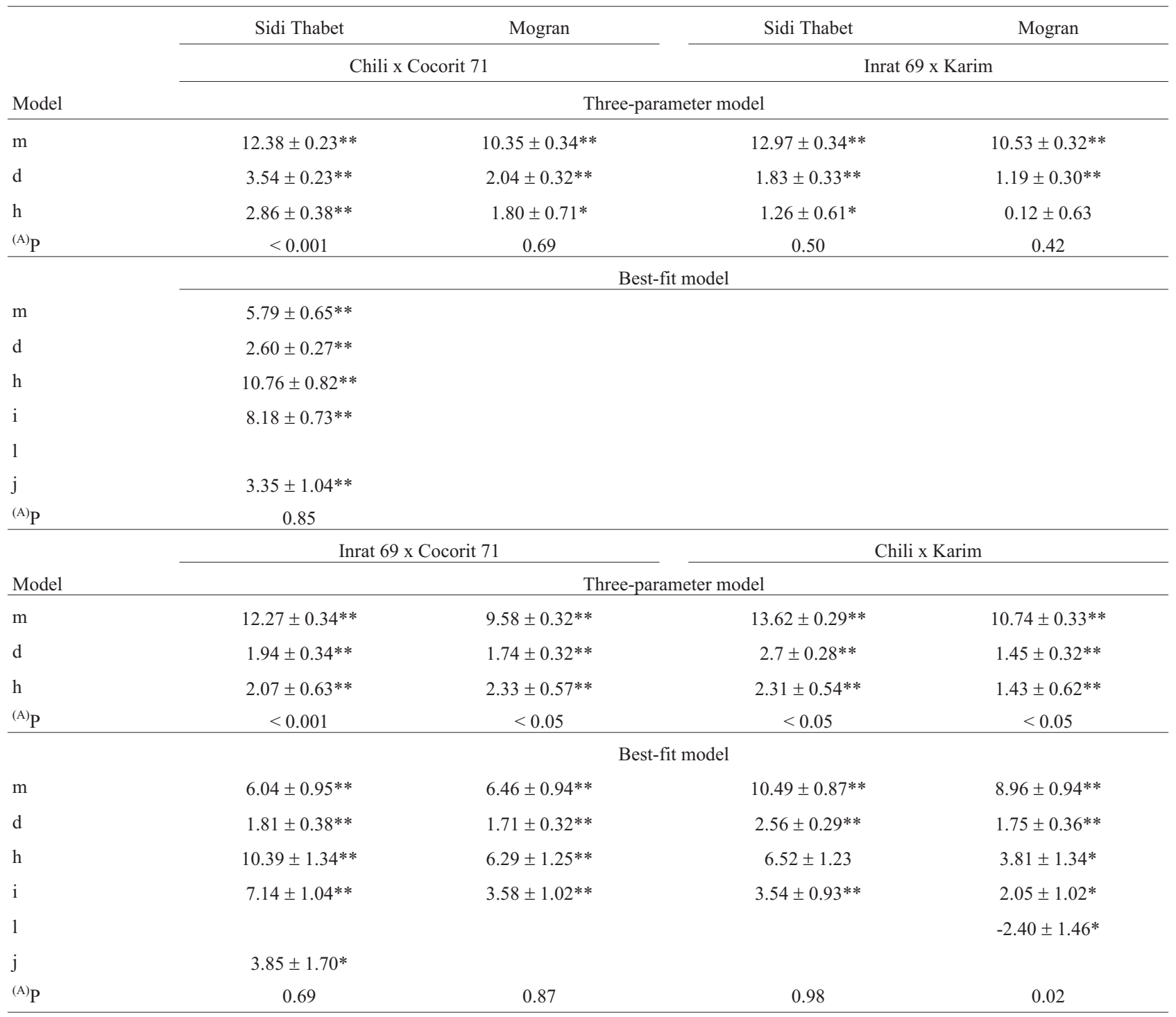

Mean (m), additive (d), dominance (h), additive $x$ additive (i), dominance $x$ dominance (l), additive $x$ dominance (j) genetic effects. $*, * *$, indicate that means and gene effects are statistically different from zero at $\mathrm{p}<0.05,0.01$, respectively.

(A) $=$ Probability of adequateness of model. 
additive (i) effect was significant in the majority of cases; the dominance $\mathrm{x}$ dominance (1) effect was significant in one case, and the additive $\mathrm{x}$ dominance $(\mathrm{j})$ effect was significant in two cases. Generation mean analysis of the non-segregating generations in the present study showed that the estimates of environment $x$ dominance and of environment $\mathrm{x}$ additive effects were not significantly different from zero in all crosses, and the four-parameter models were fitted (Table 3).

The estimates of the components additive variance, dominance variance, environmental variance and $h_{n}^{2}$ are presented in Table 4. For the cross Chili x Cocorit 71, environmental variance was higher at Mogran, additive variances were more pronounced than all other components, and their values were 8.84-9.28. Dominance variances were negative and not significant. The values of $\mathrm{h}_{\mathrm{n}}^{2}$ varied, depending on the testing site, ranging from $64 \%-85 \%$. For the Inrat $69 \times$ Karim cross, the environmental variances were similar at both sites. Additive variances were more pronounced at Mogran, with a range of 5.86-6.43. At both sites, $h_{n}^{2}$ was similar, with a range of $50 \%-53 \%$. For Inrat $69 \times$ Cocorit 71, the environmental variance range was 7.07-8.3. Additive variances were negative. Therefore, $h_{n}^{2}$ was not estimated. For the cross Chili x Karim, the environmental variance was 2.00-3.83. Additive variances were more pronounced at Mogran, with a range of 2.6-4.45. Heritability was similar between the sites, ranging from $48 \%-53 \%$.

\section{Discussion}

In all four populations, the means of the parents $\left(\mathrm{P}_{1}\right.$ and $\mathrm{P}_{2}$ ) had a tendency to be more extreme and contrasting than the means of the $F_{1}$ and $F_{2}$ generations. The backcrosses $\mathrm{BC}_{1} \mathrm{P}_{1}$ and $\mathrm{BC}_{1} \mathrm{P}_{2}$ had means that tended to be similar to those of their respective recurrent parents. These results confirmed that the choices of parents for the present study

Table 3 - Estimates of the genetic, environmental and genotype $x$ environment interaction components $( \pm$ SE) of generation means.

\begin{tabular}{|c|c|c|c|c|}
\hline & Chili x Cocorit 71 & Inrat $69 \times$ Karim & Inrat $69 \times$ Cocorit 71 & Chili x Karim \\
\hline $\mathrm{m}$ & $12.22 \pm 0.22 * *$ & $11.86 \pm 0.26^{* *}$ & $11.61 \pm 0.23 * *$ & $12.44 \pm 0.27 * *$ \\
\hline d & $2.44 \pm 0.22 * *$ & $1.56 \pm 0.26^{* *}$ & $1.81 \pm 0.23 * *$ & $2.13 \pm 0.27 * *$ \\
\hline $\mathrm{h}$ & $2.45 \pm 0.34 * *$ & $0.78 \pm 0.45$ & $2.98 \pm 0.36^{* *}$ & $2.31 \pm 0.45 * *$ \\
\hline e & $1.87 \pm 0.20 * *$ & $1.62 \pm 0.22 * *$ & $1.72 \pm 0.18 * *$ & $1.82 \pm 0.22 * *$ \\
\hline
\end{tabular}

Mean (m), additive (d), dominance (h) genetic effects; (e) environmental effect.

$*, * *$, indicate that means and gene effects are statistically different from zero at $\mathrm{p}<0.05,0.01$, respectively.

(A) $=$ Probability of adequateness of model.

Table 4 - Estimates of variance components \pm SE and narrow-sense heritability $\left(\mathrm{h}^{2}\right.$ ) in four crosses at two sites (Mogran and Sidi Thabet), with two replications.

$\mathrm{V}_{\mathrm{E}} \quad \mathrm{V}_{\mathrm{A}} \quad \mathrm{V}_{\mathrm{D}} \quad X^{2}(3 \mathrm{df}) \quad \mathrm{h}_{\mathrm{n}}^{2}$

Chili x Cocorit 71

\begin{tabular}{|c|c|c|c|c|c|c|}
\hline & Sidi Thabet & $1.55 \pm 0.30 * *$ & $8.84 \pm 2.91 * *$ & $-2.46 \pm 1.73$ & $\mathrm{~s}$ & 0.85 \\
\hline & Mogran & $5.08 \pm 1.04 * *$ & $9.28 \pm 5.50^{*}$ & $-0.48 \pm 3.79$ & ns & 0.64 \\
\hline \multicolumn{7}{|c|}{ Inrat 69 x Karim } \\
\hline & Sidi Thabet & $5.79 \pm 1.01 * *$ & $5.86 \pm 4.19$ & $-1.16 \pm 2.97$ & ns & 0.50 \\
\hline & Mogran & $5.52 \pm 0.96^{* *}$ & $6.43 \pm 5.13$ & $0.79 \pm 3.60$ & $\mathrm{~ns}$ & 0.53 \\
\hline \multicolumn{7}{|c|}{ Inrat $69 \times$ Cocorit 71} \\
\hline & Sidi Thabet & $7.07 \pm 0.91 * *$ & $-3.56 \pm 4.88$ & $4.02 \pm 3.89$ & $\mathrm{~ns}$ & $0 \mathrm{~A}$ \\
\hline & Mogran & $8.3 \pm 0.11^{* *}$ & $-3.86 \pm 5.35$ & $-48.35 \pm 4.26$ & $\mathrm{~ns}$ & $0 \mathrm{~A}$ \\
\hline \multicolumn{7}{|l|}{ Chili x Karim } \\
\hline & Sidi Thabet & $2.00 \pm 0.42 * *$ & $2.6 \pm 3.02$ & $0.74 \pm 2.18$ & ns & 0.48 \\
\hline & Mogran & $3.83 \pm 0.81 * *$ & $4.45 \pm 3.28$ & $-2.15 \pm 2.34$ & ns & 0.53 \\
\hline
\end{tabular}

$\mathrm{df}=$ degrees of freedom, calculated as the number of generations minus the number of estimated variance parameters.

$\mathrm{ns}=$ non-significant, $\mathrm{s}=$ significant.

$*, * *$, indicate that variance components are statistically different from zero at $\mathrm{p}<0.05,0.01$, respectively.

$\mathrm{A}=$ values assumed to be zero, due to negative estimates. 
were contrasting, which is a prerequisite for generation means analysis, as proposed by Mather and Jinks (1982). Generation means analysis has been used to study the inheritance of other complex traits in wheat, such as resistance to yellowberry (Bnejdi and El Gazzah, 2008), carbon isotope discrimination (Rebetzke et al., 2006), spike length (Sharma et al., 2003), plant height, number of heads per plant, number of grains per spike and grain yield per plant (Novoselovic et al., 2004).

Depending on the cross and experimental site, in most cases the variation in the generation means fitted a digenic epistatic model. This finding indicated that improvement of grain protein content would be moderately difficult compared to a situation in which an additive-dominance model is a better fit, and more favourable than for a tri-genic epistatic effect. The results agree with those of KraljevicBalalic et al. (1982), who found that, for grain protein content in bread wheat, most of the variation was due to additive and non-additive genetic variation. Similar results were reported by Ketata et al. (1976) and Joshi et al. (2004) in Triticum aestivum. An additive effect only was reported by Chapman and McNeal (1970) and Zahid et al. (2007).

The results of the present study revealed the limitation of most quantitative genetic studies based on the assumption of negligible epistasis. Many cases of significant epistasis have been reported for this trait in barley (Kaczmarek et al., 2002) and bread wheat (Kraljevic-Balalic et al., 1982).

For the crosses Chili x Cocorit 71 at Sidi Thabet and Inrat $69 \times$ Karim at Mogran and Sidi Thabet, the additive-dominance models were adequate. This indicated that the mode of gene action was site-dependent. The presence or absence of epistasis may depend upon the environment in which the plant material was evaluated and thus may not always be related to the inherent capacity of a genotype (Sunil and Singh, 2003). Kumar et al. (2003) reported that the genetic system governing grain protein content was highly additive. When an additive-dominance model was adequate, the magnitude of the additive (d) gene effect was greater than those of dominant (h) gene effects, indicating the major role of additive gene effects compared to dominance effects in controlling variation in grain protein content. With respect to epistatic effects, additive $\mathrm{x}$ additive effects were significant in all cases when a di-genic model was applied. Dominant $x$ dominant effects (1) were significant only for one case, and dominant $x$ additive (j) effects only for two cases. This situation is more favourable than the presence of dominant $\mathrm{x}$ dominant and dominant $\mathrm{x}$ additive effects in all cases. Epistasis of the additive $\mathrm{x}$ additive (i) type as observed in this experiment could be exploited in a breeding programme with the additive component, since it can be fixed by selection. Nevertheless, the additive $\mathrm{x}$ dominance (j) and dominance $x$ dominance (l) types of interactions may not be an advantage in developing inbred varieties, as these are not fixable by selection.
Generation means analysis of genotype and genotype $x$ environment interaction indicated that the non-interactive model was fitted. This situation is more favourable than the presence of environment $x$ dominance and environment $x$ additive effects.

Maximum likelihood estimates of environmental variance were higher at Mogran than at Sidi Thabet. The additive variance component was not consistent between crosses and sites and was higher for the cross Chili $\mathrm{x}$ Cocorit 71 . The dominance variance component varied between crosses and sites.

Our results showed $h_{n}^{2}$ values which were moderate to high, suggesting a large participation of the genetic effects on phenotypic expression of grain protein content, and also that selection for the trait should be highly efficient. These results are similar to those reported by Ekiz et al. (1998) and Sharma and Sharma (2007). From a breeder's point of view, the $h_{n}^{2}$ estimates from the two sites show that the Chili x Cocorit 71 cross has the greatest chance of genetic improvement. Selections in later generations with increased homozygosity, where additive and additive $\mathrm{x}$ additive variances are established, are recommended. For further increase in the grain protein content of durum wheat, it is suggested that an appropriate environment should be chosen, so that the character will show relatively simple inheritance.

\section{Acknowledgments}

We thank Dr Colin Hanbury (Department of Agriculture and Food, Western Australia) for his helpful editorial comments and corrections of our manuscript.

\section{References}

Baenziger PS, Clements RL, McIntosh MS, Yamazaki WT, Starling TM, Sammons DJ and Johnson JW (1985) Effect of cultivar, environment, and their interaction and stability analyses on milling and baking quality of soft red winter wheat. Crop Sci 25:5-8.

Bartlett MS (1937) Some examples of statistical methods of research in agriculture and applied biology. J R Stat Soc (Suppl) 4:137-183.

Blanco A, Simeone R and Gadaleta A (2006) Detection of QTLs for grain protein content in durum wheat. Theor Appl Genet 112:1195-1204.

Bnejdi F and El Gazzah M (2008) Inheritance of resistance to yellowberry in durum wheat. Euphytica 163:225-230.

Chapman SR and McNeal FH (1970) Gene effects for grain protein in five Spring Wheat crosses. Crop Sci 10:45-46.

Cowley CR and Wells DG (1980) Inheritance of seed protein in crosses involving 'Hand': A Hard Red Winter Wheat. Crop Sci 20:55-58.

Crow JF (1987) Population genetics history: A personal view. Annu Rev Genet 21:1-22.

Duffield RD, Croy LI and Smith EL (1972) Inheritance of nitrate reductase activity, grain protein, and straw protein in a Hard Red Winter Wheat cross. Agr J 64:249-251. 
Ekiz H, Kiral A, Akçin A and Simsek L (1998) Cytoplasmic effects on quality traits of bread wheat (Triticum aestivum L.) Euphytica 100:189-196.

Entz MH and Fowler DB (1989) Response of winter wheat to N and water: Growth, water use, yield and grain protein. Can J Plant Sci 69:1135-1147.

Guthrie DA, Smith EL and McNew RW (1984) Selection for high and low grain protein in six Winter Wheat crosses. Crop Sci 24:1097-1100.

Haunold A, Johnson VA and Schmidt JW (1962) Genetic measurement of protein in the grain of Triticum aestivum L. Agr J 54:203-206.

Johnson VA, Whited DA, Mattern PJ and Schmidt JW (1968) Nutritional improvement of wheat by breeding. In: Finaly KW and Shepard KW (eds) Proc $3^{\text {rd }}$ In Wheat Genet Symp. Plenum Press, New York, pp 457-461.

Joshi SK, Sharma SN, Singhania DL and Sain RS (2004) Combining ability in the F1 and F2 generations of diallel cross in hexaploid wheat (Triticum aestivum L. em. Thell.) Hereditas 141:115-121.

Kaczmarek Z, Surma M, Adamski T, Jezowski S, Madajewski R, Krystkowiak K and Kuczynska A (2002) Interaction of gene effects with environments for malting quality of barley doubled haploids. Theor Appl Genet 43:33-42.

Kearsey MJ and Pooni HS (1996) The Genetical Analysis of Quantitative Traits. Chapman and Hall, London, 381 pp.

Ketata H, Smith EL, Edwards LH and McNew RW (1976) Detection of epistatic, additive, and dominance variation in Winter Wheat (Triticum aestivum L. em Thell.). Crop Sci 16:1-4.

Kraljevic-Balalic M, Stajner D and Gasic O (1982) Inheritance of grain proteins in wheat. Euphytica 63:121-124.

Kramer TH (1979) Environmental and genetic variation for protein content in winter wheat (Triticum aestivum L). Euphytica 28:209-218.

Kumar A, Thakur KS, Sethi GS and Bhandari JC (2003) Combining ability analysis for grain yield and some other morpho-physiological traits in winter $\mathrm{x}$ spring wheat hybrids. Crop Res 26:334-338.

Lynch M and Walsh B (1998) Genetics and Analysis of Quantitative Traits. Sinauer Associates, Inc, Sunderland, 980 pp.

Mather K and Jinks JL (1982) Biometrical Genetics. 3rd edition. Chapman and Hall, London, 396 pp.

Millet E, Zaccai M and Feldman M (1992) Paternal and maternal effects on grain weight and protein percentages in crosses between hexaploid and tetraploid high protein and lowprotein wheat genotypes. Genome 35:257-260.
Novoselovic D, Marijana B, Drezner G, Gunjaca J and Lalic A (2004) Quantitative inheritance of some wheat plant traits. Genet Mol Biol 27:92-98.

Pleijel H, Mortensen L, Fuhrer J, Ojanpera K and Danielsson H (1999) Grain protein accumulation in relation to grain yield of spring wheat (Triticum aestivum L.) grown in open-top chambers with different concentrations of ozone, carbon dioxide and water availability. Agric Ecosyst Environ 72:265-270.

Rebetzke GJ, Richards RA, Condon AG and Farquhar GD (2006) Inheritance of carbon isotope discrimination in bread wheat (Triticum aestivum L.). Euphytica 150:97-106.

Rharrabti Y, Villegas D, García del Moral LF, Aparicio N, Elhani S and Royo C (2001) Environmental and genetic determination of protein content and grain yield in durum wheat under Mediterranean conditions. Plant Breed 120:381-388.

Rowe KE and Alexander WL (1980) Computations for estimating the genetic parameters in joint-scaling tests. Crop Sci 20:109-110.

SAS Institute (1990) SAS/STAT user's guide, v. 6. $4^{\text {th }}$ edition. SAS Institute, Cary.

Schnell FW and Cockerham CC (1992) Multiplicative vs. arbitrary gene action in heterosis. Genetics 131:461-469.

Sharma S and Sharma NY (2007) Estimates of variation and heritability of some quantitative and quality characters in Triticum turgidum L. ssp. durum (Desf.) Acta Agr Hung 55:261-264.

Sharma SN, Sain RS and Sharma RK (2003) Genetics of spike length in durum wheat. Euphytica 130:155-161.

Sunil K and Singh D (2003) Detection and estimation of component of genetic variation for root characteristics, plant height and seed yield at various growth stages and environments in Indian mustard. Brassica 6:41-45.

Terman GL, Ramig RE, Dreier AF and Olson RA (1969) Yieldprotein relationships in wheat grain, as affected by $\mathrm{N}$ and water. Agr J 61:755-759.

Troccoli A, Borelli GM, De Vita P, Fares C and Di Fonzo N (2000) Mini review: Durum wheat quality: A multidisciplinary concept. J Cereal Sci 32:99-113.

Zahid A, Saif Ullah A, Ali AK and Muhammad J (2007) Genetic analysis of protein, lysine, gluten and flour yield in bread wheat (Triticum aestivum L.). Pakistan J Biol Sci 10:19901995.

\section{Associate Editor: Márcio de Castro Silva Filho}

License information: This is an open-access article distributed under the terms of the Creative Commons Attribution License, which permits unrestricted use, distribution, and reproduction in any medium, provided the original work is properly cited. 